\title{
BINDING LOGICS IN ART ${ }^{1}$
}

\author{
Sílvia Pinto \& Moisés de Lemos Martins
}

\begin{abstract}
The work of art produced in its origins was only much later recognized as such. Similarly, the artistic function of current art objects in the future may become accidental again. In fact, at no time has art ever answered exclusively to aesthetic demands. From these assumptions by Walter Benjamin (1936-1939/1992), we will attempt to apply to art the concepts of "binding" (original of ethology) and of "linking networks" (used in neuroscience) to explain distinctive aspects of image metaphysics, shared by art and religion. From a historical perspective, we will attempt to show the evolution of art in three main binding logics: art as a magical activity (also in relation to index logic); art as mimesis; and art as language. The image, or rather the multiple realities we call "image", takes each one of these links, in an exchanging or simultaneous way, since image is their heiress. Taking into account the present context of media images hypervisibility, we aim, with this study, to show the importance of art and its mythical-religious ascendance in what concerns media image redefinition.
\end{abstract}

\section{Keywords}

Aesthetics, image-picture, magic-mimesis-language, media image, visual arts

\begin{abstract}
Resumo
A obra de arte produzida nos seus primórdios só muito mais tarde foi reconhecida como tal. Na mesma ordem de ideias, a função artística da obra de arte atual, no futuro, poderá tornar-se novamente acidental. Com efeito, em época alguma, a arte respondeu a exigências unicamente estéticas. Partindo destes pressupostos de Walter Benjamin (1936-1939/1992), tentaremos aplicar à arte os conceitos de "vinculação" (com origem na etologia) e de "redes de vinculação" (utilizado em neurociência), para explicar aspetos característicos da metafísica da imagem, comuns à arte e à religião.Seguindo uma perspetiva histórica, tentaremos mostrar a evolução da arte segundo três principais lógicas de vinculação: a arte como atividade mágica (também na sua relação com a lógica do índice); a arte como mimesis; e a arte como linguagem. A imagem, ou melhor, as múltiplas realidades que designamos por "imagem", assume cada um destes vínculos, alternada ou simultaneamente, pois deles é sua herdeira.Tendo em conta o atual contexto de hipervisibilidade de imagens mediáticas, esperamos, com este estudo, mostrar a importância da arte e da sua ascendência mítico-religiosa na redefinição da imagem mediática.
\end{abstract}

\section{Palavras-chave}

Artes visuais; estética; imagem; imagem mediática; magia-mimesis-linguagem

\footnotetext{
'The first version of this article was presented at the IAMCR Congress, Braga - 2010 and as a poster at the ECREA Congress, Hamburg, 2010. Later, some sections of the study were developed in the doctoral thesis For a Semiotics of Light (2015) referenced in bibliography, separately. However, the thesis "Binding Logics in Art", as such, remains original and unpublished.
} 


\section{INTRODUCTION}

The work of art produced in its origins was recognized as such only much later. Likewise, the current work of art has acquired the artistic function, which in the future may become accidental again. This idea of Walter Benjamin (1936-1939/1992, pp. 86-87) assumes another - that changes in terms of social function of art, often seen as symptoms of a crisis in the communication between art and the public, contain the signs of a rupture and renewal with regard to a set of bindings to the other, to life, death, history or time, which we will call "binding logics".

The term bonding [of bond: that which binds or, figuratively, establishes a relation], original from ethology and developed by psychologist John Boulby in the 1950s, refers to our need to establish specific emotional ties. Daniel Goleman (2006) uses the expression linkage networks to talk about the great neural networks of our main affective forces. These neural circuits not only interact in various combinations in love, friendship, compassion, or affection for animals, but also operate, to a greater or lesser extent, in areas such as spiritual longing, passion for open spaces or deserted beaches. Linkage networks are established whenever any type of neural relationship is established with someone or something. The brain responds to the illusion created by the images with the same neural circuits with which it responds to real life. Images invade our brain, just like life in general, from the smallest interaction.

As we learned from Malraux (1965/2000, p. 11), a crucifix was not initially a sculpture, just as a Madonna was not a painting (that is, an object of art). The photograph does not appear to have been an exception in this respect. As Debray (1994, p. 33) argues, image has always assumed a mediating function between the living and the dead, man and the gods, communities and cosmologies, the visible and the invisible. Benjamin knew well the different requirements imposed on art.

At no time has art responded to solely aesthetic requirements. Gothic sculptors served God by making statues for their faithful; the portraitists aimed at achieving similarity; the peaches and hares of a Chardin had their place in the dining room above the family meal table. The artists, in some cases, indeed very rarely, suffered as a result of this; art as a whole benefited; it was like that in all great artistic periods. In particular, the naive conviction that they only 'copied nature' was as salutary to the painters of these happy times as theoretically unjustifiable. (Benjamin 1982/2009, p. 728)

Following a historical perspective, we will attempt to show the evolution of art of different artistic vocations - from magic-religious activity to art (as we know it today). In other words, from the three main binding logics in art, which we consider to be more relevant throughout the ages: [1] art as a magical activity (also in relation to index logic); [2] art as mimesis; [3] art as language; and [4] art under the index logic. The image, or rather the multiple realities we call "image," takes each one of these links, alternatively or simultaneously, since image is their heiress. 
As Giulio Carlo Argan (1984, p.15) rightly observed in 1984, in our time, more than in any other period, the world is occupied with art, and never, as today, has painting had such high prestige. During the seventies, each city wanted to have its museum, as at the dawn of the eleventh century, when each city wanted to have its own cathedral. Jean Clair (1992, pp. 9-14) rightly points out that today it is the cult of art that regulates the cultural transhumance of Western tourism. There are few works of art that have resisted to the secular ties with their land and their motives and remain in their original place of exhibition and worship. In the twentieth century, circulating became a value in itself, independent of any judgment expressed on the objects introduced in the circuit. Jean Clair highlights a direct relationship between the proliferation of media outlets and the museums of Modern Art and their crisis, as if the compulsion to preserve their works was the attempt to mask the premonition of an end.

However, Malraux (1965/2000, pp. 11-12) points out that museums have imposed on the viewer a totally new relationship with the work. Until the nineteenth century, only in the eyes of the painter was a painting a painting. To everyone else, painting was always something else. The museum suppresses the portraits while eradicating the function from the works of art. It does not recognize saints or Christ; objects of veneration, likeness, imagination or possession, but only images of things, different from the things themselves. From this specific difference, it removes its reason for being. The museum resurrected a set of arts while killing others, whose domain remains vast and complex. When Benjamin writes that in the age of reproducibility of the work of art "it is the aura that fades," it refers to this shift from the place of worship of works, from their homeland, to the place of mass occurrence. Such a place has now been extended to the online circulation of the cybermuseum.

This route will allow us to understand not only the historical shift from the postmodern move from an aesthetic of analogy to an aesthetic of contact, but also to rethink our place among the various historical phases of creation - our yearning to exercise 'magical' power over existence; our need to imitate and to cause to love what we imitate; our need to cause to see and be seen - the need for bonds. This critical perspective will also enable us to understand what photography as a social practice has in common with photography as an artistic practice, and to reconnect both to the tradition of sacred images, truth, magic and folly images, to love and to death, which have always been the founding driving forces of artistic creation.

\section{Art AS A MAgiCAl ACTIVITY}

Different researchers from prehistory seem to agree on the first function or motivation that would be behind the production of the first known object images. The painter from the Paleolithic era is both the painter and the hunter who believes himself to be in possession of the object itself, from the moment he has his image. Its representation is not a beautiful object of contemplation, but a project of action that counts as anticipation of the desired effect - a powerful instrument at the service of subsistence, fertility, and the 
need to secure descendents. The depiction and the thing being depicted are still one and the same, as well as the desire and its realization. The only differentiation between image and reality seems to be in the time that separates them (Gombrich, 1986; Hauser, 1951).

For Debray (1994, pp. 13-43), art comes to the picture when magic retreats. Indeed, the notion we create of art - which is Greek - is conceived in mimesis. But if the art of the beginning of time may have been "magic" only involuntarily, the aspects that persist from it did not spring solely from the "encounter between panic and technique," as the French author argues. Images, whether they provoke relief, terror, or delight, always contain the power of an effect. What changes, according to places and times, is their ability - and that of those to whom they are addressed - to respond to their call. The inscription, which can be read in a funerary or votive statue, is always the result of a bond or a vow - a covenant - that is established through it.

Unlike mimesis, a concept that will dominate Western art from antiquity to modernism, depiction here is not a canonized projection of the past, but a visualization image of a promising future. From this point of view, this practice does not seem far from the difficult exercises of imagination in which we are introduced today as part of the most current studies and practices of positive thinking. Nevertheless, to us, heirs of the differentiation between reality and appearance, it may seem that our contemporary condition in everything distances itself from the former, and that magical thinking in no way characterizes us. However, both manipulation and torture, as well as advertising and cinema, take advantage of this knowledge: that the rationalism of the image has little effect on men when faced with what Antonio Damásio (2003) called "emotionally competent objects" - stimuli sufficiently capable of triggering maps of preexisting neural circuits.

Given the tradition of the image as the image of man (which opposes the thesis of abstraction as the first image), we can say that the primary function of religious-imageart is to cause someone who is absent to be present through the figuration of his image. The Latin origin of the word image (imago) indicates just that - effigy, statue (funerary or not). According to the narrative by Plínio, o Velho [Pliny, the Elder] (c.1470-1561, vol. XXXV, pp. 1084-1120), painting emerged when it was first possible to circumscribe the shadow of a human being using a line. This shadow-picture of the beginnings shows us the birth of Western artistic depiction as a negative emergence, under the sign of an absencepresence - the absence of the body and the presence of its projection.

The main purpose of Plínio, o Velho's [Pliny the Elder's] narrative is to describe the founding gesture of pottery and drawing, which tradition has extended to painting and sculpture by modeling. But the myth takes us further when it inserts us in a lit room where the two lovers love and say goodbye, their shadow is projected on the wall, and the girl, in an anticipatory gesture of the longing that she would feel in the absence of her lover, fixes the outline of the silhouette of the object of her love. It is Plínio [Pliny] who tells us that painting emerged from the beginning of the outline of the human shadow. The fable of the ceramist's daughter also tells us that painting emerged since Man loved and knew the fear of his loss.

As Victor Stoichita (2008) explains, in the thesis that we follow as a reference, the historical reality of the beginnings of the image puts us, therefore, before an unmistakable 
fact of the metaphysics of the image, whose origin can be sought in the interrupted erotic relation, in the separation, in the being that departs, where the substitutive character of the image results. The first function of the image is, thanks to its resemblance to the absent model, one of mnemonic support: to make present that which is absent. The second function derives from the fact that the shadow belongs to someone who has been involved in a contact relationship. The shadow image has the function of recording a mark of a missing person, immortalizing their presence in the form of a time-fixed image, thus acquiring a propitiatory ${ }^{2}$ value.

The story that Plínio [Pliny] ( $15^{\text {th }}$ century) evokes, by resorting to a fable originating in Egypt, thus conveys a set of aspects common to Greek and Egyptian cultures. As Victor Stoichita (2008) elaborates, in his Brief History of the Shadow, both ancient Greece and Egypt established a symbolic link between the shadow, the soul, and the idea of human beings' doubles. In Egypt, there were two shadows that manifested themselves at different moments: while the man lived, the shadow was exteriorized in the black shadow (khaibit); at the moment of death, at the moment when the black shadow disappeared, the $\mathrm{Ka}$ (the clear shadow of an aerial color) assumed the function of double, thanks to the magical embodiment of the soul in the Ka of the mummy statue. The mummy statue thus became the embodiment of eidolon (an image without substance) in the colossi (the animated double), in practice, the "living" substitute of the dead body, enlivened in the shadow-soul of the Ka.

Both Egyptologists and Hellenists argue that the statue emerges for one of two reasons: either to take the place of a god, or to take the place of a dead person. As Bazin $(1945 / 1981$, p.9) confirms, in the origins of painting and sculpture lies the complex aspect of the mummy. The Egyptian religion, all directed against death, made the survival of beings depend on the material perenniality of bodies, thereby satisfying a fundamental need of human psychology: defense against time. It was natural to save the life from death in the flesh and in the bones. Thus, the first Egyptian statue is the mummy of the man tanned and petrified in the natron. But the preservation of the body was not enough. It was necessary that his faithful image also be preserved, since the primary function of the Egyptian statue was to save the being by the appearance.

Probably, thanks to this motivation - that of saving the being by the appearance - the portrait is the genre that, par excellence, seems to have been consecrated to the resemblance, like a service - a truthful service in which homage is paid, which is not far from religious service (Nancy, 2006, 38). Thus, as a substitute for a person, the statue was necessarily seen as animate. For this reason, as Levin (1971, p. 27) points out, the Egyptians channeled the sunlight through small open slits in the roof of the pyramids, studied to direct the light in the form of a spotlight, towards the statues that were in

\footnotetext{
${ }^{2}$ In the Old Testament, the mercy seat was the symbol of God's throne, that is, it symbolizes the presence of God. On the Day of Atonement, the high priest sprinkled the blood of animals sacrificed on and before the mercy seat for the remission of the sins of the people of Israel (Leviticus 16:14-15). In this propitiatory character of mummified statues, the same kind of value that is attributed to Christian relics seems implicit. (From the lat. reliquia, neutral plural of reliquium, "thing left"). Whether it refers to a god or a saint, in either case, the relic is precious or rare, as an object that has belonged to it, or its own body, even if it is only a part of it, that people worship.
} 
their interior, to literally "animate" the statues with the light of the sun, according to the natural movement of the star.

According to Ernst Gombrich (1985, pp. 106-110), the Egyptian sculptor was designated as "the one who keeps alive," for eternalizing the lives of the dead. Just as the Great Sphinx was conceived to serve as a vigilant sentinel forever, likewise, the portrait of the owner of a tomb given to the vision of the peasants on his property is not the mere record of his past life, but a presence that has the power to watch over the work of his employees through the endless cycle of years. While the scenes of daily life have to be read, their sequence is purely conceptual, not narrative. The images simultaneously represent what was, what is and what will be, as an eternal present. Doing and recording here are merged in the same promise to keep, in lucid pictures, the evanescent character of time.

\section{ArT AS Mimesis}

As Benjamin (1936-1939/1992, p. 75) observes, the work of art has always been reproducible. Men could always imitate what they had done before. But the discovery of the differentiation between original and copy may have been a mere "chain effect" (Hanfmann quoted in Gombrich, 1989) at the beginning of the imaging process. With the Greeks, the emergence of the reproduction-for-sale industry (the foundry and the coinage) 3 removed the image and the object from the context for which they had been conceived, introducing them to private homes - it was about endowing art with a new function, since this art situation was previously non-existent. For this reason, we can say that the Greeks invented art.

The theory of mimesis, which Plato develops between A República [The Republic] (2010) [ $4^{\text {th }}$ century b.C.] and The Sophist (2012) [ $4^{\text {th }}$ century b.C.], marks the triumph of the mirror over the shadow. The shadow image (phantasmata), given the ambiguous status attributed to it, plays a secondary role in the art of copying, yielding the place of greater importance to the mirror image (eidola), which, by submitting to the laws of mimesis, will become superior to it. It is by virtue of Platonism that the work of art will bend to the demands of the specular paradigm and the projection of the shadow will be limited to a marginal role, which does not mean that it will be eliminated from the arsenal of depiction. However, it will become the poor relative of any reflection, and its status will remain vague and marked by obscure powers 4 .

In the course of the history of Western depiction, it was Plato who struck the first blow to the "shadow." But it will be the first theory of art, in the midst of the Renaissance, to explicitly claim for itself the specular paradigm. In the founding text of the painting of modern times, De Pictura, Leon Battista Alberti (1435) presents the theory of the new art, under the sign of Narcissus. This new idea of pictorial image is assumed as a consequence of an erotic act, as in the Plinian myth, but, reversing the roles: here the painting concerns the self, not the other.

\footnotetext{
${ }_{3}^{3}$ Deepening of the first reproduction techniques in: Benjamin (1936-1939/1992, pp. 75-76) and Sicard (2006, pp. 23-104).

4 In order to delve deeper into the "victory of the mirror over the shadow," see Victor Stoichita (2008). Breve storia dell'ombra, Milano: Il Saggiatore (pp. 29-39).
} 
A little over a century later, Giorgio Vasari (1568), in a debatable overlap between the founding myth's two versions - Pliny's and Alberti's - will create a third version of it. Referring to Pliny's text, Vasari transforms the portrait, from the shadow of the other into a shadow self-portrait, reaffirming the relation of early art to the specular paradigm, which can be deduced from the myth of Narcissus.

Apart from the figurative impossibility and the theoretical paradox that Philippe Dubois (1992, pp. 118-123) demonstrates in the Photographic Act5, only with the emergence of the photographic device will it be possible to ensure the direct depiction of that which is depicted. Notwithstanding the contradictions of the specular device, Stoichita (2008, p. 39) confirms what Vasari sought to make clear, that the art upon which he intended to make history was that which embodied the "state of the shadow in the state of the mirror," whose archetype would be the myth of Narcissus, elected by Alberti. Indeed, the art that made history until the advent of Modern Art was that which Plato declared to be the superior and only acceptable art - the "art of copying," governed by the laws of mimetic depiction.

Interestingly, according to data from Neuroscience (Goleman, 2006), the brain responds to the illusion created by the images with the same circuits it responds to in real life. Indeed, studies of screen-viewer contagion show how the "movies we see" literally and metaphorically dominate our brain. On the other hand, Swedish researchers have found that, whenever we look at a photo of someone whose face reveals a strong emotion, our facial muscles automatically begin to imitate the expression we see, triggering in us the corresponding feelings. This phenomenon, called "reflex imitation," is more a brain-to-brain bridge whereby we involuntarily expose ourselves to emotional influences, reproducing preexisting, more or less desirable neural circuits.

Emotions are contagious both in life and in art because "a thing is real if it is real in its consequences" (Goleman, 2006, 37). Thus, the brain responds to situations of empathy, real or represented, "lighting" certain preexisting neural circuits. When two people feel a relationship, their physiologies are attuned: the eyes meet, the bodies approach, and in the strongest relationships, the postures and movements between people are copied. Aristotle identified the pleasure of imitation in the learning process. The circuits of this resonance seem to be incorporated in the human nervous system itself, since, even in the womb, the baby already synchronizes its movements with the rhythms of human speech. By contrast, when the relation is not established, the voice and the bodies draw the picture of a disconnection - the impossibility of establishing bonds.

\section{Art as language}

For Rosalind Kraus (2002, pp. 63-75), the naturalistic ambition with which the Impressionists left their ateliers to conquer the world gradually became an increasing

\footnotetext{
${ }^{5}$ On the figurative impossibility of the self-portrait of shadow, Dubois (1992, p. 119) writes the following: "the hand that draws, in particular, can never be drawn by drawing: to this end, it should stop, to immobilize its shadow, but immediately interrupt the very act of drawing. Or it may well run after itself, and as quickly as it can, as it will never let itself be caught."
} 
introversion and imprecision, a loss of intelligibility. The Impressionist style became an obstacle to the creation of bonds between the painter and his subject. The pictorial illusion was fragmented into deposits of pigments, layers of paint and unpainted white spots of canvas. Impressionist canvases are unfinished notes of light and color, in the form of juxtaposed spots - that which was hitherto known as "sketches."

To date, for a painting to be considered as such, a unifying vision was needed to structure and link the elements. Impressionists, transforming the visible unity of their own introspection into a systemic organization of perception, have created a new function for art - art as language or system of signs - for many, the first chapter of Modern Art.

According to the definition by Filiberto Menna (1983, p. XI), Modern Art arises from the theoretical and operative acquisition of the conventional and abstract nature of artistic language. This acquisition operates a veritable epistemological break in the problematic of art, in relation to a naturalistic conception of language, problematizing the assumption of an immediate correspondence between language and reality. According to this conception, the art that did not perceive this passage of no return, is not Modern Art, but only chronologically contemporary.

Filiberto Menna (1983) also shows how the "analytical line of Modern Art" contributes to putting an episteme founded on continuity and resemblance in the field of art, thus opening the way to an episteme based on discontinuity and difference. In Symbolism, art is still a science of analogy, in short, hermeneutics as a technique for deciphering the signs of nature. With Impressionism, and in particular with Cézanne and Seurat, painting becomes semiology (p. 96). Art-Language's Conceptual Art and its most extremely analytical tips mark the culmination of the refoundation of the language of Modern Art, leading the process of abstraction of artistic language to the ultimate consequences. $A$ language is supposed to communicate, to serve to share, or to make common to others, our experience of the world. However, art starts to become language at the moment of the foundation of Aesthetics as a discipline, by claiming its right to autonomy in relation to any social, functional, hedonistic or moral function.

Walter Benjamin (1936-1939/1992, p. 83) justifies the emergence of "art for art" as a reaction to the nineteenth-century crisis, which manifested itself in "the theology of [pure] art." Here, artistic practice ceases to be mimesis - an experience deduced from nature as a metaphysical principle of revelation - to become poiesis - with no end beyond its own doing. The word "autonomy" renders the condition of what it is for itself, and only for itself, as Steiner (1993, p. 58) refers. With the emergence of Modern Art and the breakdown of the mimetic pact that governed the recognition of the world, until the end of the Classical Age, the art that affirms its autonomy is reduced to its own language.

By the end of the sixteenth century, however, language is not an arbitrary being, which proliferates indistinctly, not even a mere episode in the history of language 6 . Language was given to the world by God and marked ("signed") 7 by its image and shadow,

\footnotetext{
${ }^{6}$ For all the considerations made on language until the sixteenth and seventeenth centuries, see Michel Foucault, M. (1998 [1966]), "The Prose of the World" in Words and Things. An Archeology of Human Sciences (pp. 73-99), Lisbon: Edições 70.

7 In Foucault's (1966/1998, p. 81) work we refer to, the chapter on "marks" is entitled "signatures.
} 
just like all things in nature. There is no difference between the visible marks that God placed on Earth and the readable words of Holy Scripture or other ancient texts that the tradition chose. The relationship with the texts is of the same nature as the relation to things - both propose to men as riddles to be deciphered. And it is from "signatures" that men use, in either case, to know. The experience of language belongs to the same archaeological network to which depiction and knowledge of the things of nature belong. To know is to take ownership of the system of similarities, making them close and in solidarity with one another.

According to George Steiner (1998, pp. 87-89), the breaking of the covenant with language, which reflects our relationship with God, constitutes one of the most profound revolutions of the spirit in the history of the West and defines Modernity itself. Here, the act of semantic trust, which occurs in language when it is able to establish links between beings, and between them and the objects to which they refer, is undone. The alliance between words, images and things entailed that being is sufficiently "sayable".

Notwithstanding the reduction of art to semiotics, as is evident from the most analytical researches in Modern Art, the similarity and its figures never cease, however, to act impromptu within the new episteme, finding, in the field of art, a terrain with an abundance of possibilities for new situations with new analytical trends.

To paraphrase two great authors, "art is a special way of thinking" (Rosenberg, 1972) in which new "ways of making worlds" are invented (Goodman, 1978); It cannot, therefore, renounce its hermeneutic function, according to the most strictly analytical project, nor its inalienable demand for appointment - this is its primary condition as language. And this is the abyss of this encounter: the poetic denomination and the communicative denomination (Menna 1999, p. 99).

\section{ART UNDER THE LOGIC OF THE INDEX}

Walter Benjamin (1936-1939/1992, pp. 77-83), in the principle of technical reproduction, predicts an unprecedented change in the history of culture - the loss of the aura or of its "here and now" - the unique existence of the encounter, which constitutes the remnant of the ritual function, before it becomes a secularized ritual. Whether by appropriating works of art in their entirety or by earning their place among artistic procedures, what is taken away from technical reproducibility is the principle of authenticity, which, with the secularization of art, takes the place of the value of the worship of its works. The loss of the aura, of the "here and now," cancels out the unique testimony of that unmatched encounter.

In contemporary times, photographs have become the visual experience par excellence. Much of the work of Arte Povera, Land Art or Body Art is produced to be photographed, since it is often not possible to know the work, either by the dimensions of the works in locus or by its ephemerality, except through their photographic record. Thus, photography began by invading the exhibition spaces of art and the field of criticism, at the moment of affirming modernity itself, signaling the resurgence of a new form of aura. 
Today, as Susan Sontag (1986, p. 133) would say, all art "aspires to the characteristics of a reproducible object."

Historically, it is during the process of abstraction, in progress in Impressionist painting, and the subsequent contingency of light in the pictorial depiction, that light will give the photograph a certain transcendence. Thanks to the character of photography as an acheiropoiete 8 image, for the early photographers, light is the "writing" of nature, as Nadar (1900) writes in his book entitled Pencil of Nature.

The atmosphere of mystery and awe that involved the emergence of photography allowed for some of the strangest practices, such as "photographing spirits" and photographing people on their deathbed. Mortuary photography became one of the main activities of the nineteenth-century commercial photographer. And, according to Krauss (2002, pp. 26-29), Balzac elaborated his "Theory of Specters," using light to produce his "specters" in photographic experiments. As Margarida de Medeiros (2010, p. 17) notes, "the automatic dimension of the photographic image has summoned many ghosts, positive and negative, euphoric and dysphoric since its invention".

Occupying an ambiguous place at the confluence between science and spiritualism, photography participates in positivist thought and, at the same time, takes part in the intelligibility order of metaphysicians. In this regard, photography seems to substantiate, at the level of the mechanisms of imagery depiction, the ideals of impartiality and objectivity of the positivist paradigm of modernity, which would deal with the crisis of pictorial depiction opened by Impressionism. By joining science to transcendence (the "astonishment" of which Frade (1992) speaks, and the mysticism that lends itself to its interpretation), photography fulfills the dream of a universal language, assuming itself as "the privilege of a modern look "(Sérgio Mah, 2003).

According to André Bazin (1945/1992, p.10), in Modernism, photography becomes the motto of an aesthetic with a dual meaning: it emphasizes photography as a practice of realistic doxa and projects a new field of interests for the visual arts, releasing them from the obsession of resemblance and reality. If the photograph in its appearance assumes itself as a mirror, or analogon of reality, later, in the 1960s, a critical reaction occurs, from different disciplinary territories, denouncing the conception of photography as a non-copy mediated from the real, evidencing the aspects of photography as a transformation of the real against the supposed transparency of the medium. Interestingly, this conception, which signals a distrust of the objectivity of the photographic image and which triggered a return in force to the artefact and the intervention of the artist in the media, is based on the belief of an inner truth, which is not confused with the appearances of what is real.

As Philippe Dubois (1992, p. 110) shows, despite the various positions taken by critics $^{9}$, the emergence of photography revealed a relation between depiction and real-

8 An acheiropoiete image is an image produced without the intervention of a human hand (like Plato's images), since the role of the photographer is minimized as an intermediary whose mediation between depiction and that which is real is neutral, analogical and automatic.

9 The positions taken by the critics on the principle of reality in photography are as follows: the mimesis discourse, the 
ity, which already existed from the very beginnings of depiction itself - Peirce's notion of index. Painting, as a theoretical device, was already worked over by the problem of the contiguity of the referent, as much as by the problem of similarity. Whether it is the historical origin (the Lascaux caves), the fabulous origin (the stories of the shadows of Pliny and Plato) ${ }^{10}$, or mythological origin (the mirrors of Narcissus and Medusa), in every case, depiction emerged through contact.

The conception of photography based on Peirce's notion of the index has as its starting point its technical nature, the principle of luminous impression. But it is clearly distinguished from the two preceding conceptions, by endowing the indicial image with a unique value, determined solely by its referent. Here, photography includes the category of signs including "smoke (the sign of a fire), projected shadow (the sign of a presence), scar (mark of a wound), ruin (a trace of what was there), the symptom (of a disease)" (Dubois 1992, p. 44).

The vestigial principle marks only a moment in the photographic process as a whole. However, it is this moment when photography is "birthed," which gives it a new genetics, different from painting. Only during the instant of the act can photography be regarded as a "pure vestige act" or, according to Barthesean terminology, "a message without a code" (Barthes 1989, p. 125). In that instant of forgetting the codes, there is a failure in which, by light, an existence is recorded, as in the book of life. Through the extreme uniqueness of this relation of connection, the index-image refers back to a given referent, designating it and witnessing its existence - "this was," with which Barthes (1989, pp. 17-101) enunciates the noema of photography and which constitutes "impossible science of being unique".

Photography is interpreted in congruent terms by the history of art. However, this does not define its essence. The attempt to classify photography seems to always want to be avoided, since it does not constitute a corpus, "only a few bodies" (Barthes, 1989, pp. 16-22). For good and / or evil, the index-picture confronts us with our relationship with other objects and other subjects. The "stubbornness of the referent," which the image manifests, reveals the state of our soul.

Historically, Peirce's notion is part of a global project of moving from the icon category to the index category. This passage, viewed as a semiosis, and not just as a mark of modernity, is a true historical shift, where a (classic) aesthetic of mimesis, analogy and semantics (the order of metaphor) would give way to an aesthetic of vestige, contact and referential contiguity (the order of metonymy). The order of the index thus reveals itself as a unique conceptual instrument which gives an account of how the new forms of Contemporary Art function.

Rosalind Krauss (2002) delves deeper into the emergence and radicalization of index logic in Contemporary Art, not only clearly identifying the space given to photography in the movements of the second avant-garde of the twentieth century, such as Body Art or

discourse of the code and the discourse of deconstruction, as well as their corresponding indicial status.

${ }^{10}$ From this point of view, Plato's shadows and reflections (phantasmata) seem to correspond to the modern definition of index. 
Land Art, but also recognizing in these manifestations the influence of the photographic model of the trace, trail and vestige - displayed on the body or marked on the floor - as an index of a gesture and symptom of a time. The ready-made Duchampian itself, conceived as instantaneous, becomes the trait of a particular event - an act of enunciation - the equivalent of verbal signifiers of the "this" or "what" type, which Barthes (1989, pp. 84-85) theorizes.

At one time, photography served to shake the aesthetic universe of differentiation, by introducing the unsettling eventuality of replacing qualitative difference with a simple palette of quantitative differences, as with series. This collapse of the notion of difference, with enormous impact on traditionally "distinct" artistic practices, reveals multiplicity, fiction, repetition, and stereotype throughout the artistic gesture (1989, pp. 223-224).

Unlike what Pierre Bourdieu (1989) " thought, photography constituted itself as a critical discourse that is part of a vast deconstruction project in which "art distances itself" (Krauss, 2002, p. 226), but perhaps brings us closer to each other: "Show your photos to anyone; it will show its own" (Barthes, 1989, p.18). In this regard, photography obeys less to the logic of aesthetic discourse (to the logic of the author) than to the logic of the album, the archive, the trip and the reporting. A photo can never be distinguished from its referent - "a pipe is always a pipe. "This fatality or "stubbornness of the referent" drags the photograph to the immense disorder of objects - of all objects in the world12 (Barthes, 1989, pp. 18-19).

The practice of what is multiple - whether it's hundreds of mechanically reproduced copies (such as Andy Warhol's serigraphs), or hundreds of indifferentiated photos (like those of any tourist), shakes the distinction between the original and the copy, the authors, and the others, as well as the very notion of authenticity, returning the distinction between the original and the copy to indifferentiation, as in the beginning of time. Here, the professional photographer and the family photographer are linked by the same practice.

When Moses asks God to see "his glory," God will cover his face as a sign of protection, and show him the trail of His passage (Exodus 33: 12-23). With this request that Moses directs to God, a whole tradition is inscribed in which we are inscribed, which is characterized by our insufficiency and insecurity, and by our need to see and be seen by the face of whom we love, to receive any sign of the their presence, even if it is the trail / remnant of their passage. This is the logic of the index, a concept that runs through Benjamin's entire work, and which reaches us through photographic reflection.

\footnotetext{
"For Bourdieu, photography can never be an aesthetic discourse as such, because it has no rules of its own, but borrows its criteria from other arts. It is "an art that imitates art" (Bourdieu, 1965/2003, p. 135), as if this was not a definition (attributed to André Malraux) for all arts. From the sociological point of view, photography serves as social index or proof of family unity. It is an object of regulated exchanges and stereotyped activities. Its scope is that of domestic rites of worship (Bourdieu, 1965/2003, pp. 57-58).

${ }^{12}$ As Georges Kubler (1998, pp. 13-14) would say, all objects mark the passage of time. The photograph seems to substantiate Kubler's vision of a broadening of the concept of art, in order to encompass all kinds of man-made objects, by matching the universe of objects in general with the History of Art.
} 


\section{ConcLusions}

We define "art as a magical activity,"13 "art as mimesis," and "art as language," as the bonding logics whereby man is linked by art (in the anthropological and broad sense of the term) to life and death, to God and to the other, to memory and to dream. We identify these three main logics of man's relation to art, which, being historically differentiated, are as old as contemporary, and in most cases, interchangeable and overlapping. Magic-mimesis-language follow each other in time, drawing the historical path of non-aesthetic demands imposed on the art of their beginnings until their autonomy and, simultaneously, their motivations and achievements.

[Magic] Both the production of magical artefacts and the tradition of the image, as the image of man (seen in mimesis), are linked to the substitutive character of the imageobject, in which the mnemonic function is vital, since its objective is to depict, that is, literally, "make present an absent being." Everything indicates that the primary function of the portrait-statue (both Egyptian and Greek) was to save the being by its appearance, and, thus, to stop the evanescent character of the time. Although with different contours, the practice of portraiture prolongs this tradition, as it remains at the center of image production today.

[Mimesis] For Michel Melot (2015), the bond that blends the image is not of the order of things, but of the order of relation: "it is always the image of something or of someone, of whom it is not even a copy" (p. 12). The differentiation between the original and the copy, a possible "chain effect" (Hanfmann) at the beginning of the imaging process, becomes the protagonist in mimesis, with which we become familiar through manual, mechanical, and, later, digital reproduction. Aristotle emphasized the pleasure of imitation as necessary to the learning process. Neuroscience studies go further, suggesting that the need for mimesis seems to be justified by the enjoyment of positive relationships (which we establish with people, images, spaces and / or things). Pleasure and displeasure are vital somatic markers for our homeostatic balance. The importance of the images to which we are exposed, and which we copy consciously or by "reflex imitation" (by virtue of the neural contagion between us and them), is so vital to our mental and emotional health that, by virtue of the hyper-visual nature and hyper-information to which we are exposed, we are led to opt for disconnection. Technological mimesis undoubtedly corresponds to an inversion (Martins, 2001, p. 132) ${ }^{14}$.

[Language] From the thinking of Michel Foucault, the images are dealt with in the context of the crisis of depiction and of the dissociation between words and things - the crisis of the "true image," according to the expression coined by Hans Belting (2011) which is, above all, the crisis of belief in the relation between truth and image, and the subsequent disillusionment. From this crisis, which began as a crisis of a religious nature and ended up in several domains, including in the image itself, modernity and the movement of "art for art" (or art as language) emerged.

\footnotetext{
13 "Art as a magical activity" and "art under the logic of the index" are associated with the indicial character of the objectimage, equally common to the concepts of "art as life" of Performance and Body Art.

14 On technological mimesis, see Communication and Society, 22, 2012, a number organized by Nelson Zagalo \& Pedro Branco, devoted to "Creative Technologies."
} 
Nowadays, from the scientific image to the proof-image, from the visual arts to marketing, no sphere seems to be immune to "imagery," or the universe of private life, or what is left of it. However, as Sicard (2006, p. 299) points out, the engraving, a product of the craftsman's art, does not create the same looks as the image of photographic technique, just as the photographic device does not manufacture the same world as digital programs, whose property escapes individuals. The history of glances is as much a part of the history of images and of their transmission and production as of the history of vision devices. The history of images and glances always inscribes itself in the history of the media.

An image always evokes other images, because, as Belting (2014, p. 11) explains, images comprise historically contingent responses and, in this regard, maladjusted as concerns the needs of successive generations. This is why more and newer images are always required (even if they only appear to be "new") to respond to timeless questions with regard to being, common to art and to religion. The importance of art and its mythical-religious rise in redefining the media image lie in interdependence between the image and the medium. In anthropological terms, arte is among the first means of extending one's glance. From the shadow of origins to the specular paradigm, and of this to "electronic mirrors" (Belting, 2014, p. 45), arte updates the images of our relationship with the world using means placed at our disposal in every time period. Indeed, regardless of the available means, art constitutes the place where lost meanings are forged in processes of transmission, association and reminiscence of images, in short, the place of symbolic production.

Traduzido por Sílvia Pinto e revisto por Victor Ferreira

\section{BibLIOGRAPHIC REFERENCES}

Argan, G. C. (1984). Arte e critica d'arte. Rome-Bari: Laterza.

Barthes, R. (1989) [1980]. A câmara clara. Lisbon: Edições 70.

Barr, D. (2003). Imagens (pictures) para una representación contemporânea. Madrid: Mimesis.

Bazin, A. (1945/1981). Ontologie de l'image photographique. In A. Bazin, Qu'est-ce que le Cinéma? (pp. 9-17). Paris: Édition du Cerf.

Belting, H. (2011). A verdadeira imagem. Entre fé e a suspeita das imagens: cenários históricos. Lisbon: Dafne Editora.

Belting, H. (2014). Antropologia da imagem: para uma ciência da imagem. Lisbon: Editora KKYM + EAUM.

Benjamin, W. (1936-1939/1992). A obra de arte na era da sua reprodutibilidade técnica. In W. Benjamin, Sobre Arte, Técnica, Linguagem e Política (pp. 71-113). Lisbon: Relógio d’Água.

Benjamin, W. (1982/2009). Passagens. Belo Horizonte: Editora UFMG; São Paulo: Editora Oficial Estado de São Paulo.

Bourdieu, P. (Ed.) (1965/2003). Un arte medio. Ensayo sobre los usos sociales de la fotografia. Barcelona: Editorial Gustavo Gili. 
Clair, J. (1992). Critica della modernitá. Milan: Umberto Allemandi \& C.

Damásio, A. R. (2003). Ao encontro de Espinosa: as emoções sociais e a neurologia do sentir. Mem-Martins: Publicações Europa-América.

Debray, R. (1994). Vida e morte da imagem. Uma história do olhar no Ocidente. Petrópolis: Vozes.

Dubois, P. (1992). O acto fotográfico. Lisbon: Vega.

Foucault, M. (1966/1998). As palavras e as coisas. Uma arqueologia das ciências humanas. Lisbon: Edições 70.

Goleman, D. (2006). Inteligência social. A nova ciência do relacionamento humano. Lisbon: Temas e Debates Actividades Editoriais, Lda.

Gombrich, E. H. (1985). A história da arte. Rio de Janeiro: Zahar Editores.

Gombrich, E. H. (1959/1986). Arte e Ilusão. Um Estudo da Psicologia da Representação Pictórica. S. Paulo: Martins Fontes.

Hauser, A. (1951). História social da arte e da cultura, Vol. 1: Os tempos pré-históricos. Grécia e Roma. Lisbon: Vega.

Krauss, R. (2002). O fotográfico. Barcelona: Editorial Gustavo Gili.

Levin, Kim (1971). The eye of Ra. In Ashbery, J. \& Hiess, T. B. (Eds.), Light in Art (pp. 23-36). New York: Collier Books.

Melot, M. (2015). Uma breve história da imagem. Vila Nova de Famalicão: Húmus \& CECS.

Malraux, A. (1965/2000). O museu imaginário. Lisbon: Edições 70.

Martins, M. L. (2011). O que podem as imagens. Trajeto do uno ao múltiplo. In Martins, M. L.; Oliveira, M.; Miranda, B. \& Godinho, J. (Eds.), Imagem e Pensamento (pp. 129-135). Coimbra: Grácio Editor.

Medeiros, M. (2010). Fotografia e verdade. Uma história de fantasmas. Lisbon: Assírio \& Alvim.

Menna, F. (1983). La linea analitica dell'arte moderna. Torino: Piccola Biblioteca Einaudi.

Nancy, J.-L. (2006). La mirada del retrato. Buenos Aires - Madrid: Amorrortu.

Platão (Séc. IV a.C./2010). A República. Lisbon: Fundação Calouste Gulbenkian.

Platão (Séc. IV a.C./2012). O sofista. Lisbon: Fundação Calouste Gulbenkian.

Plinio, o Velho [Caio Plinio Secondo] (c. 1470-1561). Historia naturale. Libro XXXV, pp. 1084-1120. VeneziaFerrara: Giacomo Vidale.

Pinto, S. (2015). Para uma semiótica da luz. Da visão mítica aos regimes escópicos da Contemporaneidade. Doctoral thesis, University of Minho, Braga, Portugal.

Sicard, M. (2006). A fábrica do olhar. Imagens de ciência e aparelhos de visão [Século XV-XX]. Lisbon: Edições 70.

Sontag, S. (1986). Ensaios sobre fotografia. Lisbon: Publicações Dom Quixote.

Steiner, G. (1993). Presenças reais. As artes do sentido. Lisbon: Editorial Presença.

Stoichita, V. (2008). Breve storia dell'ombra. Milano: Il Saggiatore.

Zagalo, N. \& Branco, P. (Eds.) (2012). Comunicação e Sociedade, 22. 


\section{BIOGRAPHICAL NOTES}

Sílvia Pinto is a Plastic \& Multimedia Artist and Assistant Professor at the Universidade Lusófona do Porto. She has participated in individual and collective exhibitions in Porto, Bologna, Berlin, Barcelona and Rotterdam (Oporto-Rotterdam Capitals of Cultural 2001); she received financial support from Calouste Gulbenkian Foundation for the Encruzilhada exhibition (2006) and was awarded the Chaves Art Biennial (2006) with the video A Preparação do Caminho. For more information see: www.silviapinto.com.pt

Summa cum Laude in Plastic Arts - Painting, by the Accademia di Belle Arti di Bologna (2001) and PhD in Communication Sciences - Specialty in Social Semiotics, from the University of Minho (2015), she essentially conducts research in the fields of Art, Communication \& Semiotics, and Visual / Cultural Studies. She published, among other articles, "Caves of Contemporaneity" (2014); "Scopic Regimes" (2014), "From light and sense" (with Madalena Oliveira, 2016); "Light and shadow as extensions of man" (with Moisés Martins \& Madalena Oliveira, 2017).

E-mail: silvia.pinto.07@gmail.com

Adress: Rua Alcino Araújo, 59 D - $3^{\circ}$ D, S, Félix da Marinha, 4410-218, Portugal

Moisés de Lemos Martins is Professor at the University of Minho. He has a PhD in Social Sciences from the University of Humanities in Strasbourg (1984). He teaches and researches in social semiotics, sociology of communication and culture, intercultural communication, Portuguese-language studies. He directs the Communication and Society Research Centre (CECS), which he founded in 2001. He is Director of the journal Comunicação e Sociedade, and also the Lusophone Journal of Cultural Studies. He presided over Sopcom, Lusocom and Confidercom. Published or edited, among other books: Lusofonia e Interculturalidade [Lusophony and Interculturality] (2015); Do Post ao Postal [From post to postcard] (with Maria da Luz Correia); Crise no Castelo da Cultura [Crisis at the Castle of Culture] (2011); L'imaginaire des medias (with Michel Maffesoli, 2011), Portugal Ilustrado em Postais [Portugal Illustrated in Postcards (with Madalena Oliveira, 2011); Caminhos nas Ciências Sociais [Pathways in Social Sciences] (2010); Comunicação e Lusofonia [Communication and Lusophony] (with Helena Sousa and Rosa Cabecinhas, 2006); Linguagem, Verdade e Poder [Language, Truth and Power] (2002); Por uma Inversa Navegação [For an Inverse Navigation] (1996); O Olho de Deus no discurso salazarista [The Eye of God in the Salazarist Discourse] (1990).

E-mail: moisesm@ics.uminho.pt

Instituto de Ciências Sociais, Universidade do Minho, Campus de Gualtar 4710-057 Braga,Portugal

* Submitted: 17-10-2016

* Accepted: 22-01-2017 